\title{
Luteal blood flow measured by Doppler ultrasonography during the first three weeks after artificial insemination in pregnant and non-pregnant Bos indicus dairy cows
}

\author{
Mubbashar HASSAN ${ }^{1)}$, Usman ARSHAD ${ }^{1)}$, Muhammad BILAL ${ }^{2)}$, Abdul SATTAR ${ }^{1)}$, \\ Muhammad AVAIS ${ }^{3)}$, Heinrich BOLLWEIN ${ }^{4)}$ and Nasim AHMAD ${ }^{1)}$ \\ 1) Department of Theriogenology, Faculty of Veterinary Science, University of Veterinary and Animal Sciences, \\ Lahore 54000, Pakistan \\ 2) Department of Statistics and Computer Science, Faculty of Life Sciences and Business Management, University of \\ Veterinary and Animal Sciences, Lahore 54000, Pakistan \\ ${ }^{3)}$ Department of Clinical Medicine and Surgery, Faculty of Veterinary Science, University of Veterinary and Animal \\ Sciences, Lahore 54000, Pakistan \\ ${ }^{4)}$ Clinic of Reproductive Medicine, Vetsuisse-Faculty, University of Zurich, Zurich CH-8057, Switzerland \\ \#Present: Clinic of Reproductive Medicine, Vetsuisse-Faculty, University of Zurich, Zurich CH-8057, Switzerland
}

\begin{abstract}
The objective of this study was to determine if there are differences in luteal size (LS), progesterone (P4), and luteal blood flow (LBF) between pregnant and non-pregnant Bos indicus dairy cows during the first three weeks after insemination, and whether these parameters are related to each other. Lactating cows $(n=13)$ of mixed parity with a body weight of $430 \pm$ $18 \mathrm{~kg}$ (mean $\pm \mathrm{SD}$ ), showing regular estrous cycle were used in the study. All cows were artificially inseminated and were classified as pregnant (embryonic heartbeat on day 30; $n=8$ ) or non-pregnant (inter-estrus interval 17 to 21 days, $n=5$ ). In order to compare the LS and LBF after artificial insemination, B-mode and color Doppler ultrasonography of ovaries were performed on days 4, 5, 6, 7 (first week), 8, 10, 12, 14, (second week), and 16, 17, 18, 19, 20, 21 (third week) in pregnant and non-pregnant cows. Results revealed that the mean LBF was consistently higher $(\mathrm{P}<0.05)$ during days 7 through 21 in pregnant cows than in non-pregnant cows. The mean LS was higher $(\mathrm{P}<0.05)$ on days 6 and 7 , and from day 17 onwards, and the mean concentration of $\mathrm{P} 4$ was higher $(\mathrm{P}<0.05)$ on days 19,20 , and 21 in pregnant cows. In conclusion, LBF is a more sensitive parameter than LS and P4 for detection of differences in luteal function between pregnant and non-pregnant Bos indicus dairy cows during the first three weeks after AI.
\end{abstract}

Key words: Bos indicus dairy cows, Doppler ultrasound, Luteal blood flow, Pregnancy

(J. Reprod. Dev. 65: 29-36, 2019)

B s indicus cows predominate in tropical and sub-tropical regions because of their adaptation to high temperatures and humidity [1], thereby having a considerable effect on the beef and dairy industries in these regions [2]. However, they exhibit lower potential for milk production than Bos taurus breed of cattle [3]. In order to optimize the milk production around the year, healthy cows must calve at 12-14-month intervals. Bos indicus cows have the potential to produce one calf per year, when maintained under favorable conditions [4]. The success of calving as a one year phenomenon relies on the early detection and timely re-insemination of non-pregnant cows $[5,6]$.

The most common method for early detection of pregnancy in cows is using transrectal B-mode ultrasonography 26-33 days post artificial insemination (AI) [7]. Alternatively, immunological detection

Received: July 4, 2018

Accepted: October 15, 2018

Published online in J-STAGE: November 4, 2018

C)2019 by the Society for Reproduction and Development

Correspondence: N Ahmad (e-mail: nasimahmad@uvas.edu.pk)

This is an open-access article distributed under the terms of the Creative Commons Attribution Non-Commercial No Derivatives (by-nc-nd) License. (CC-BY-NC-ND 4.0: https://creativecommons.org/licenses/by-nc-nd/4.0/) of pregnancy-specific substances in maternal serum, 28-35 days post AI, has been used [8-10]. These methods detect pregnancies later than the maternal recognition of pregnancy, which occurs around days 15 to 17 [11]. As these biochemical methods are relatively complex, their field application is quite restricted. Understanding of the luteal blood flow (LBF) using Doppler ultrasonography, around day 20 post AI, has emerged as a novel tool to detect and re-inseminate the non-pregnant Bos taurus cows [12,13]. Although, some information on LBF is available in Nelore cows of Bos indicus species [14], which have beef character, there is no information for milk breeds yet.

Color Doppler ultrasonography (CDU) has extended the scope of imaging from an anatomical to a physiological basis [15]. Initially, this technique was used to measure the real-time changes in LBF after induced [16] and spontaneous [17] luteolysis in Holstein Friesian cows. Furthermore, CDU was used to compare the LBF with luteal size (LS) and concentrations of progesterone (P4) during the estrous cycle of mares [18], Holstein cows [19], Italian Mediterranean buffaloes [20], and ewes [21, 22]. Subsequently, researchers became interested in using this technique to predict the pregnancy in crossbred beef cows [23], German Holstein cows [24], Italian Mediterranean buffaloes [25], mares [26], beef heifers [27], and Holstein Friesian 
cows [28]. More recently, it was used to predict the occurrence of embryonic loss based on the uterine and ovarian vascular dynamics in dairy cows [29].

Most of the research using CDU in reproductive medicine has been carried out in Bos taurus cows. Sahiwal cow is one of the established milk breeds of zebu cattle, representing Bos indicus [30]. There is very little information regarding luteal dynamics based on LBF in Bos indicus dairy cows. Therefore, the objective of this study was to determine if there are differences in luteal size (LS), progesterone (P4), and luteal blood flow (LBF) between pregnant and non-pregnant Bos indicus dairy cows during the first three weeks after insemination, and whether these parameters are related to each other.

\section{Materials and Methods}

\section{Animal care and management}

This study was approved by the Ethics Committee for the Care and Use of Experimental Animals at University of Veterinary and Animal Sciences, Lahore, Pakistan. The study was carried out during the breeding season (March-June 2015) at the Livestock Experimental Station, Jahangirabad, district Khanewal, Punjab, Pakistan. Lactating Sahiwal cows ( $n=13)$ of mixed parity $(1-3)$ and body weight 430 $\pm 18 \mathrm{~kg}$ (mean $\pm \mathrm{SD}$ ), with healthy, regular cycles were used for the study. Body condition score (BCS) was assessed at the start of the study using a 5-point scale: $1=$ emaciated to $5=$ obese [31]. Cows with a mean BCS of $3.5 \pm 0.3(3.25-3.75)$ were included in the experiment. The cows were housed in a semi-loose housing system and fed 30-40 kg green fodder (Trifolium alexandrinum), 2-3 $\mathrm{kg}$ concentrate, and $100 \mathrm{~g}$ mineral supplements per day and offered water ad libitum.

\section{Study design}

Estrus detection was carried out twice daily ( $0600 \mathrm{~h}$ and $1800 \mathrm{~h})$ using a penile-deviated teaser bull to determine the onset of standing heat (day 0). B-mode ultrasonography (My Lab30 Gold VET, Esaote, Genoa, Italy) was performed to confirm the presence of a pre-ovulatory follicle (POF). All cows were artificially inseminated using frozen semen, $12 \mathrm{~h}$ after the onset of standing estrus. B-mode ultrasonography was performed repeatedly at 12-h intervals to confirm the absence of POF (ovulation), and this day was referred as day 1 of the estrous cycle. All inseminated cows were retrospectively classified as pregnant (embryonic heartbeat on day 30;n=8) or non-pregnant (inter-estrus interval 17 to 21 days, $n=5$ ). In order to compare the LS and LBF after AI, B-mode and color Doppler ultrasonography of the ovaries were performed on days $4,5,6,7$ (first week), 8, 10, 12, 14, (second week), and 16, 17, 18, 19, 20, 21 (third week) in pregnant and non-pregnant cows. During the first and third week, sonographic examinations were carried out daily, whereas during the second week, cows were examined on alternate days. Thus, each cow was mapped 14 times, resulting in a total of 182 measurements from all cows.

\section{B-mode and Doppler sonography for luteal dynamics}

B-mode ultrasonography of ovaries was performed using a 7.5 $\mathrm{MHz}$ linear array transrectal probe. All ultrasound examinations were conducted by the same operator $(\mathrm{MH})$ between $0700 \mathrm{~h}$ to 1100 $\mathrm{h}$ and took about $25 \mathrm{~min}$ for each cow. The corpus luteum (CL) was localized on the ovary and three cross sectional images with maximum areas of the CL were displayed, recorded, and digitized using B-mode sonography. Color Doppler mode was used to assess and ensure the maximum LBF value. Three cross sectional images of the CL were frozen and recorded, avoiding flash artifacts. In order to minimize the variation caused by technical reasons, a standardized preset of the ultrasound machine was used throughout the color Doppler sonographic examinations.

\section{Data analysis and quantification of images}

Both B-mode and Doppler mode images of the CL and LBF were recorded in bitmap-format and stored on a hard drive in the ultrasound machine. The stored images were then subjected to offline analysis using computer-assisted image analysis software Image $\mathrm{J}$ (National Health Institute, Bethesda, MD, USA). The CL diameter was calculated as described earlier [32]. Each CL was cropped from the captured grey scale image for pixel analysis to measure the cross-sectional area of LS using Image J. The same software was used to quantify the area of color pixels within the CL between pregnant and non-pregnant cows (Fig. 4), which was considered as a semi-quantitative parameter of LBF. In order to minimize the chances of error, mean values of the three images were recorded during each examination.

\section{Blood samples and progesterone assay}

Blood samples from the jugular vein were collected after sonographic examinations from each cow. An 18-gauge, 3.8-cm long hypodermic needle in a $10-\mathrm{ml}$ syringe without anticoagulant was used to collect the blood. The serum was separated within $30 \mathrm{~min}$ and stored at $-20{ }^{\circ} \mathrm{C}$ until analysis. Serum concentrations of $\mathrm{P} 4$ were measured by using a commercially available double antibody radioimmunoassay kit (ImmunoTech, Prague, Czech Republic) with a ${ }^{125}$ I-labelled tracer. The inter-assay and intra-assay coefficients of variation were $6.2 \%$ and $3.5 \%$, respectively.

\section{Statistical analysis}

Normal distribution of the data was verified using KolmogorovSmirnov and Shapiro-Wilk tests. Mean values of LS, P4, and LBF were subjected to analysis of variance (ANOVA) of repeated measurements, considering the variance among the cows during three weeks post AI and using the PROC GLIMMIX procedure to determine the effects of day, group (pregnant and non-pregnant), and the group-time interaction. Least significant difference (LSD) was used as a post-hoc test to determine the difference between the days of estrous cycle. Relationships among LS, concentrations of $\mathrm{P} 4$, and LBF of both pregnant and non-pregnant cows during first, second, and third weeks were analyzed using Pearson's correlation coefficient. Correlation coefficients were classified as very good $(\mathrm{r}>0.85)$, good $(0.75<\mathrm{r} \leq 0.85)$, and moderate $(0.50<\mathrm{r} \leq 0.75)$. The data for LS, P4, and LBF were presented as mean \pm standard errors of mean (S.E.M). All data were analyzed using Statistical Analytical System (SAS 9.2 Institute, Cary, NC, USA). Probability level of $\mathrm{P}<0.05$ was considered significant. 

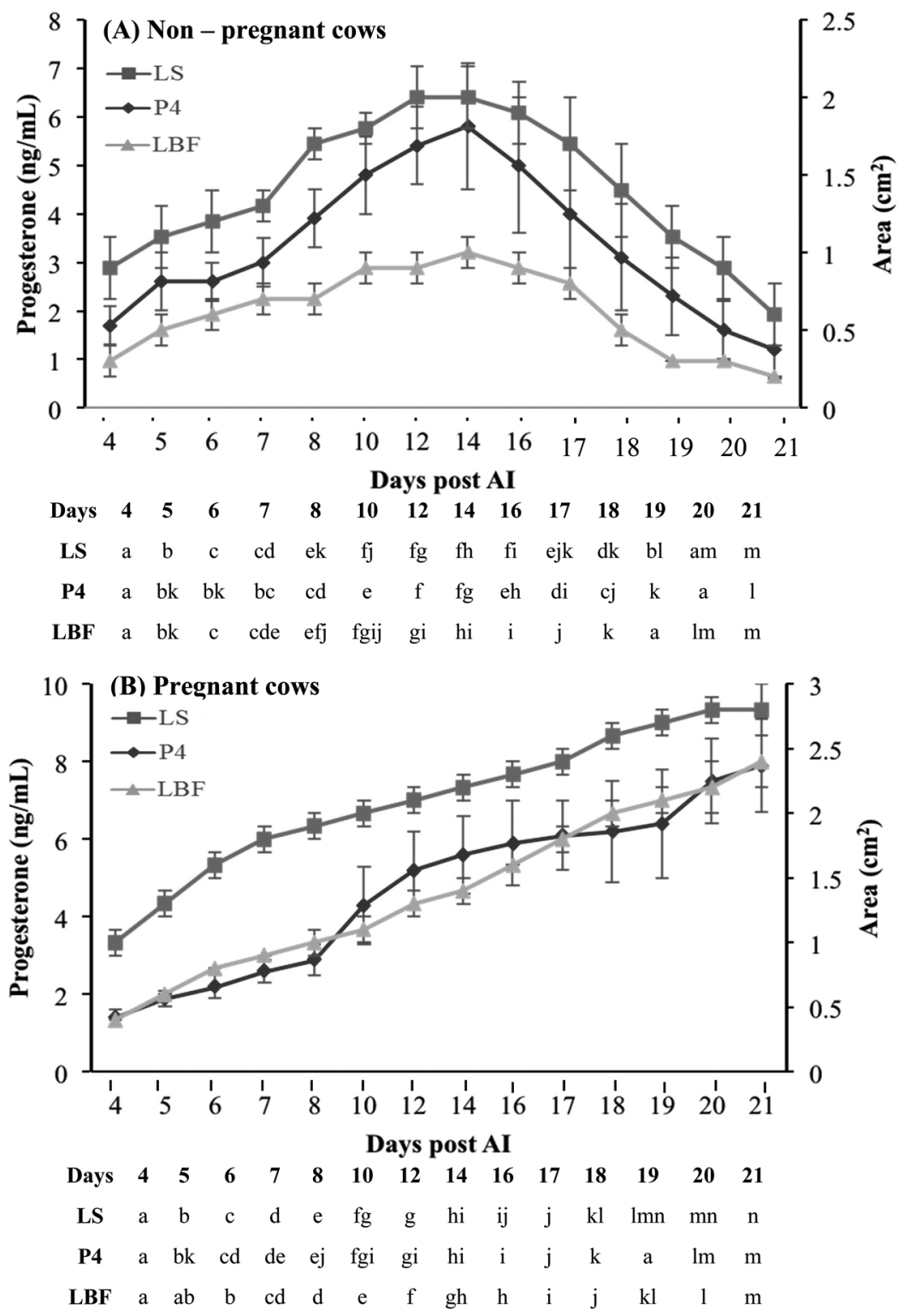

Fig. 1. (A) Represents the absolute changes in luteal size (LS), concentration of progesterone (P4), and luteal blood flow (LBF) of non-pregnant Bos indicus dairy cows $(\mathrm{n}=5)$ and $(\mathrm{B})$ signifies the relationships of LS, P4, and LBF in pregnant cows $(\mathrm{n}=8)$. Different letters indicate significant $(\mathrm{P}<0.05)$ differences between the respective days.

\section{Results}

Cyclic changes in luteal size, progesterone, and luteal blood flow

Non-pregnant cows $(n=5)$ : Changes in LS, P4, and LBF during the first three weeks post $\mathrm{AI}$ in non-pregnant cows are presented in Fig. 1A and Fig. $2(\mathrm{~A}-\mathrm{C})$. The mean LS increased $(\mathrm{P}<0.05)$ from $0.9 \mathrm{~cm}^{2}$ (day 4) to $1.3 \mathrm{~cm}^{2}$ (day 7) during the first week, and from $1.7 \mathrm{~cm}^{2}$ (day 8) to $2.0 \mathrm{~cm}^{2}$ (day 14) in the second week, whereas it declined $(\mathrm{P}<0.05)$ from $1.7 \mathrm{~cm}^{2}$ (day 17) to $0.6 \mathrm{~cm}^{2}$ (day 21) during the third week after AI. The mean LS did not differ $(\mathrm{P}>0.05)$ between days 4 (first week) and day 19 (third week), or across days
$10,12,14$, and 16 .

The concentrations of $\mathrm{P} 4$ rose significantly from $1.7 \mathrm{ng} / \mathrm{ml}$ (day 4) to $3.0 \mathrm{ng} / \mathrm{ml}$ (day 7) during the first week and increased (P $<$ 0.05 ) further from $3.9 \mathrm{ng} / \mathrm{ml}$ (day 8) up to $5.8 \mathrm{ng} / \mathrm{ml}$ (day 14) in the second week post AI. In the third week post AI, P4 decreased (P $<$ 0.05 ) from $4.0 \mathrm{ng} / \mathrm{ml}$ (day 17) to $1.2 \mathrm{ng} / \mathrm{ml}$ (day 21). None of the cows had a P4 level below $1 \mathrm{ng} / \mathrm{ml}$ on day 21 . The P4 did not differ $(\mathrm{P}>0.05)$ between days 4 and 19 and between days 12 and 14 .

The LBF increased $(\mathrm{P}<0.05)$ from $0.3 \mathrm{~cm}^{2}$ (day 4$)$ to $0.7 \mathrm{~cm}^{2}$ (day 7), indicating a two-fold rise within 3 days of the first week. In the following days, LBF rose $(\mathrm{P}<0.05)$ from $0.7 \mathrm{~cm}^{2}$ (day 8$)$ to 

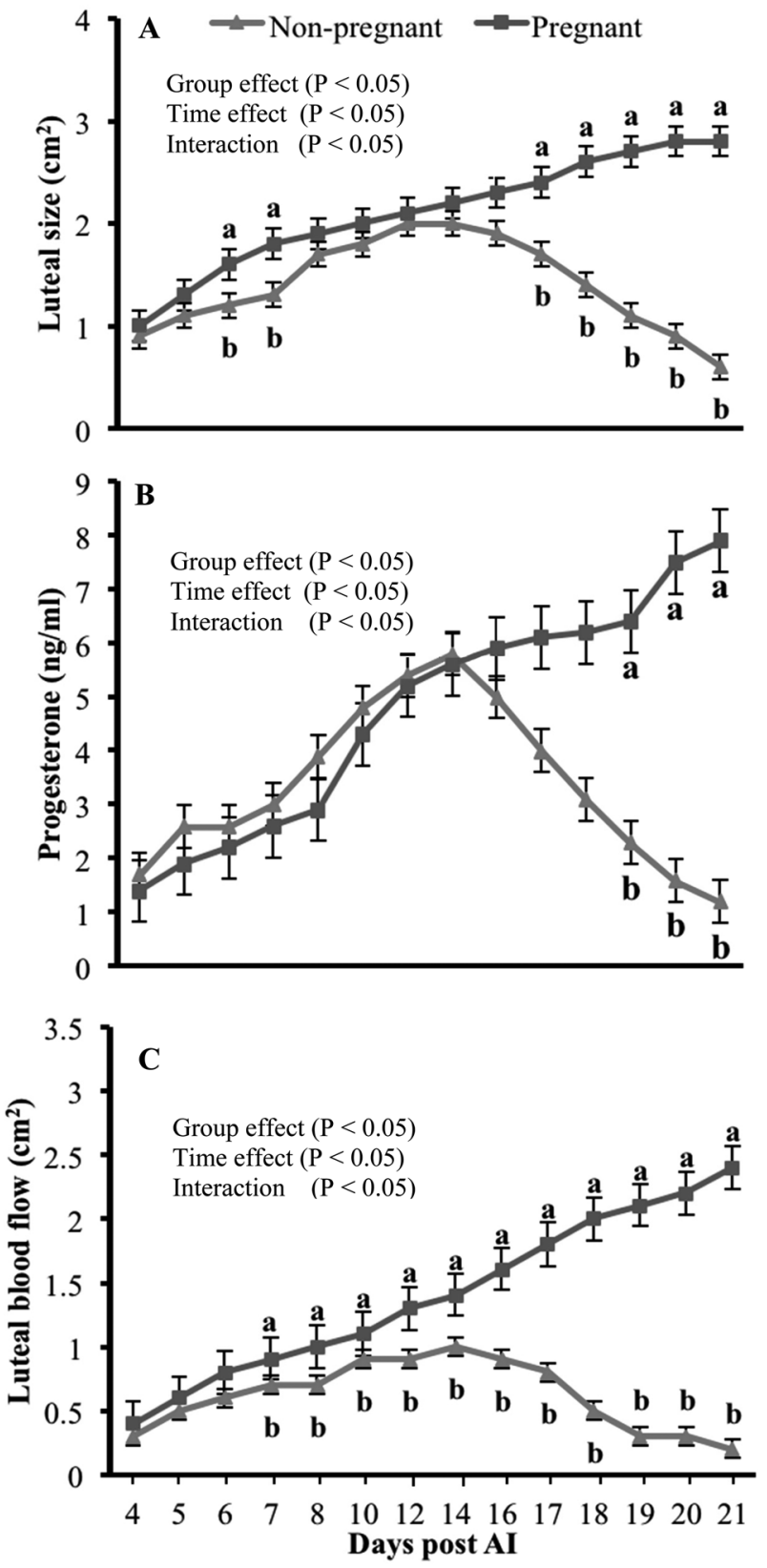

Fig. 2. (A-C) Represents the absolute changes in luteal size (LS), concentrations of progesterone (P4), and luteal blood flow (LBF) in the first three weeks post AI in pregnant and non-pregnant Bos indicus dairy cows. Different letters indicate significant $(\mathrm{P}<0.05)$ differences between the groups.

$1.0 \mathrm{~cm}^{2}$ (day 14). During the third week, LBF declined $(\mathrm{P}<0.05)$ from $0.8 \mathrm{~cm}^{2}$ to $0.2 \mathrm{~cm}^{2}$ on days 17 and 21 , respectively, as shown in Fig. 4 (A-C). However, the LBF values were similar $(\mathrm{P}>0.05)$ on days 4 and 18 .

Pregnant Cows $(n=8)$ : The pregnancy rate diagnosed at day 30 post AI using B-mode ultrasonography was $62 \%(8 / 13)$. The changes in LS, P4, and LBF during the three weeks post AI in pregnant cows are presented in Fig. 1B and in Fig. 2 (A-C). All parameters (LS, P4, and LBF) were affected by time (days; $\mathrm{P}<0.0001$ ), group (pregnant $v s$. non-pregnant; $\mathrm{P}<0.0003$ ), and group-time interactions $(\mathrm{P}<0.001)$. The mean LS increased significantly from $1.0 \mathrm{~cm}^{2}$ (day 4) to $1.8 \mathrm{~cm}^{2}$ (day 7) during the first week, and from $1.9 \mathrm{~cm}^{2}$ (day 8 ) to $2.8 \mathrm{~cm}^{2}$ (day 21) during the second and third week post AI. Furthermore, the mean LS was higher $(\mathrm{P}<0.05)$ in pregnant cows than in non-pregnant cows on days 6 and 7, and from day 17 onwards (Fig. 2A).

The $\mathrm{P} 4$ showed a rise $(\mathrm{P}<0.05)$ from $1.4 \mathrm{ng} / \mathrm{ml}$ (day 4) to 2.6 $\mathrm{ng} / \mathrm{ml}$ (day 7) during the first week and increased $(\mathrm{P}<0.05)$ further from $2.9 \mathrm{ng} / \mathrm{ml}$ (day 8) up to $5.6 \mathrm{ng} / \mathrm{ml}$ (day 14) in the second week post AI. Moreover, $\mathrm{P} 4$ consistently rose $(\mathrm{P}<0.05)$ from $5.9 \mathrm{ng} / \mathrm{ml}$ (day 16) to $7.9 \mathrm{ng} / \mathrm{ml}$ (day 21) during the third week post AI. Mean concentrations of $\mathrm{P} 4$ differed $(\mathrm{P}<0.05)$ from day 19 post AI between pregnant and non-pregnant cows (Fig. 2B).

LBF increased continuously during the first three weeks post $\mathrm{AI}$ in pregnant cows. The LBF more than doubled $(\mathrm{P}<0.05)$ from day $4\left(0.4 \mathrm{~cm}^{2}\right)$ to day $7\left(0.9 \mathrm{~cm}^{2}\right)$, as well as from day $8\left(1.0 \mathrm{~cm}^{2}\right)$ to day $21\left(2.4 \mathrm{~cm}^{2}\right)$, as shown in Fig. 4 (D-F). The LBF remained consistently higher $(\mathrm{P}<0.05)$ during days 7 through 21 in pregnant as compared to non-pregnant cows (Fig. 2C).

\section{Correlation among relative changes in LS, concentrations of $P 4$, and $L B F$}

Non-pregnant cows $(n=5)$ : Correlations between LS, P4, and LBF in non-pregnant cows are presented in Fig. 3 (A-C). A very good positive correlation $(\mathrm{r}=0.98 ; \mathrm{P}<0.05)$ was seen between $\mathrm{LS}$ and $\mathrm{P} 4$ from days 4 to 20 as well as during the first $(\mathrm{r}=0.98 ; \mathrm{P}<0.05)$ and the third week $(\mathrm{r}=0.99 ; \mathrm{P}<0.05)$. Likewise, a very good but non-significant correlation was found during the second week $(\mathrm{r}=$ $0.90 ; \mathrm{P}>0.05)$ post AI. Very good positive relationships were also noted between $\mathrm{P} 4$ and LBF from days 4 to $20(\mathrm{r}=0.95 ; \mathrm{P}<0.05)$ as well as during the first $(\mathrm{r}=0.93 ; \mathrm{P}<0.05)$ and the third week $(\mathrm{r}$ $=0.96 ; \mathrm{P}<0.05)$. In the second week after AI, LBF and $\mathrm{P} 4$ showed good positive relationships $(\mathrm{r}=0.82 ; \mathrm{P}>0.05)$.

A very good correlation was noted between LS and LBF ( $\mathrm{r}=$ 0.94; $\mathrm{P}<0.05$ ) during days 4 through 20 after AI. Moreover, we observed a good correlation in the first week $(\mathrm{r}=0.84 ; \mathrm{P}>0.05)$ and a very good correlation in the third week $(\mathrm{r}=0.93 ; \mathrm{P}<0.05)$ after AI. However, only a moderate, non-significant correlation was noted during the second week $(\mathrm{r}=0.52 ; \mathrm{P}>0.05)$ after AI.

Pregnant cows $(n=8)$ : Correlations between LS, P4, and LBF in pregnant cows are presented in Fig. 3 (D-F). A very good positive correlation $(\mathrm{r}=0.95 ; \mathrm{P}<0.05)$ was observed between LS and P4 from days 4 to 21 . Similarly, high correlations were found during the first $(r=0.98 ; \mathrm{P}<0.05)$ and the second $(\mathrm{r}=0.92 ; \mathrm{P}<0.05)$ week. A moderate non-significant correlation $(\mathrm{r}=0.74 ; \mathrm{P}>0.05)$ was noted during the third week after AI. A very good positive correlation $(\mathrm{r}=$ 0.96; $\mathrm{P}<0.05)$ was observed between $\mathrm{P} 4$ and LBF from days 4 to 21 as well as during the first $(\mathrm{r}=0.98 ; \mathrm{P}<0.05)$, second $(\mathrm{r}=0.96$; $\mathrm{P}<0.05)$, and third $(\mathrm{r}=0.91 ; \mathrm{P}<0.05)$ week after $\mathrm{AI}$ in pregnant cows. Very good positive correlations were also observed between LS and LBF from days 4 to 21 after AI $(r=0.97 ; \mathrm{P}<0.05)$ and during the first $(\mathrm{r}=0.99 ; \mathrm{P}<0.05)$, second $(\mathrm{r}=0.96 ; \mathrm{P}<0.05)$, and third $(\mathrm{r}=0.93 ; \mathrm{P}<0.05)$ week after AI. 

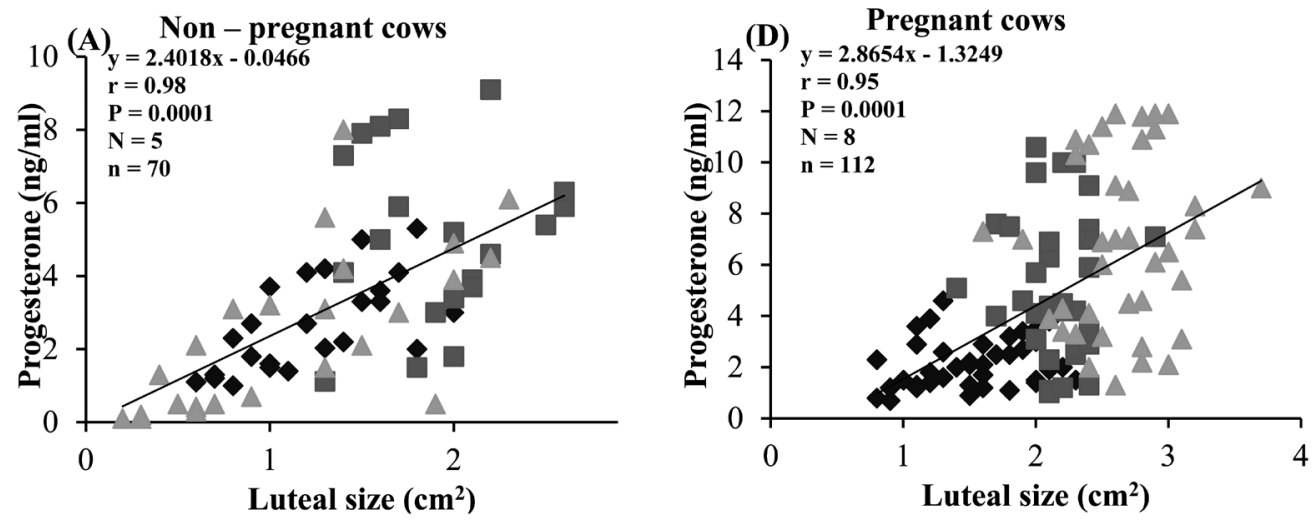

(B)

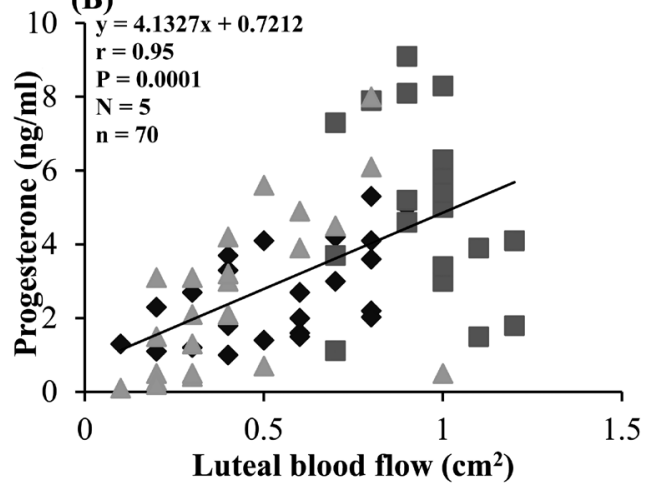

(E)

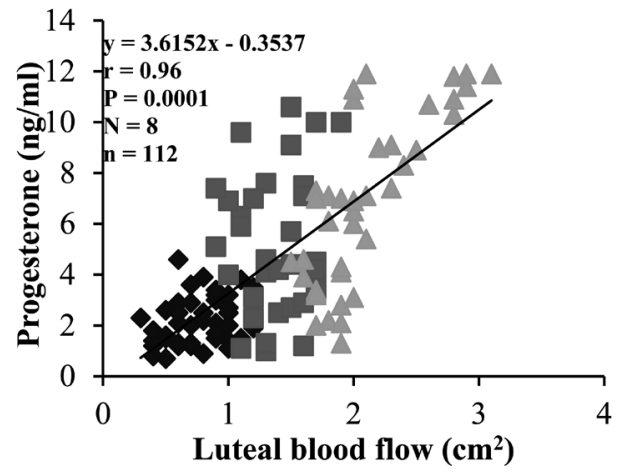

(C)

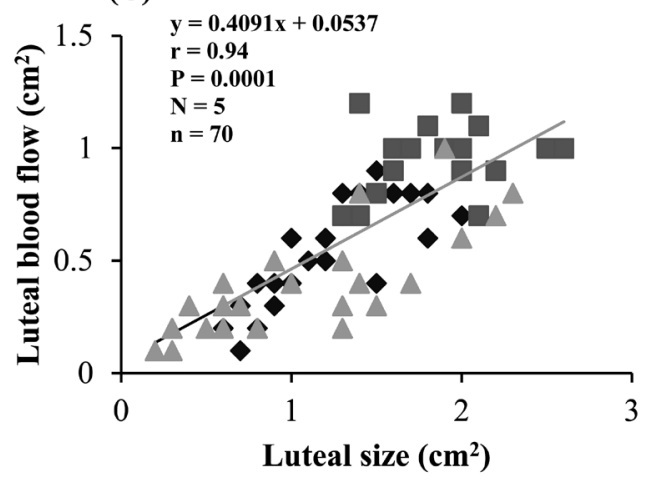

(F)

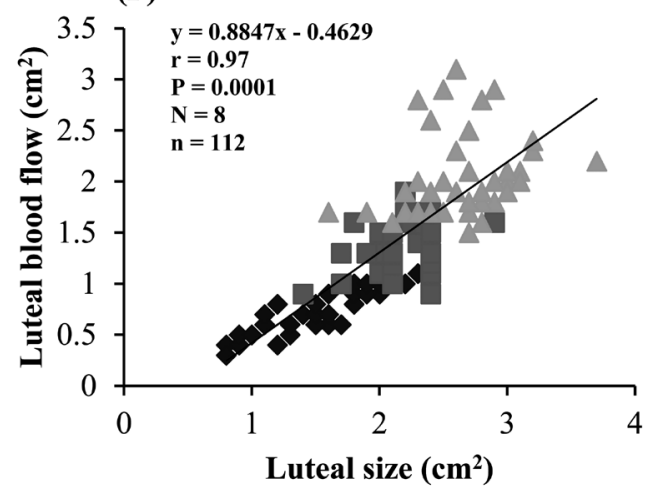

Fig. 3. (A-C) Correlations among luteal size (LS), concentrations of plasma progesterone (P4), and luteal blood flow (LBF) during the first ( $\downarrow$ ), second $(\boldsymbol{\square})$, and third week $(\boldsymbol{\Delta})$ after AI in non- pregnant $(\mathrm{n}=5)$ Bos indicus dairy cows. (D-F) Correlations among LS, plasma P4, and LBF during the first $(\diamond)$, second $(\boldsymbol{\square})$, and third week $(\boldsymbol{\Delta})$ after AI in pregnant $(\mathrm{n}=8)$ Bos indicus dairy cows.

\section{Discussion}

To the best of our knowledge, this study is the first to report the relationships among LS, P4, and LBF in pregnant and non-pregnant Bos indicus dairy cows. The salient finding of this study is that compared with LS or P4, LBF seems a better indicator of differences in luteal function between pregnant and non-pregnant Bos indicus cows. This is because LBF consistently began to differ between pregnant and non-pregnant cows on day 7, whereas LS or P4 values diverged at a much later stage, i.e., on days 17 and 19, respectively.
These findings are supported by recent studies in which LBF was significantly higher at day 7 in pregnant Holstein cows [33], and at day 9 in Saanen goats [34]. The most plausible reason for the enhanced LBF could be an increased demand of nutrients and substrates of P4 by the embryo and CL, respectively, during the elongation phase [33]. Recent evidence indicated an increased CL function during early pregnancy in temporal association with an increase in blood flow in the ipsilateral uterine artery of dairy heifers [35]. On the other hand, LBF, during the late luteal phase, was higher at days 15 or 18 , although not consistently, in pregnant $v s$. non-pregnant 


\section{(A - C) Non - pregnant cows}
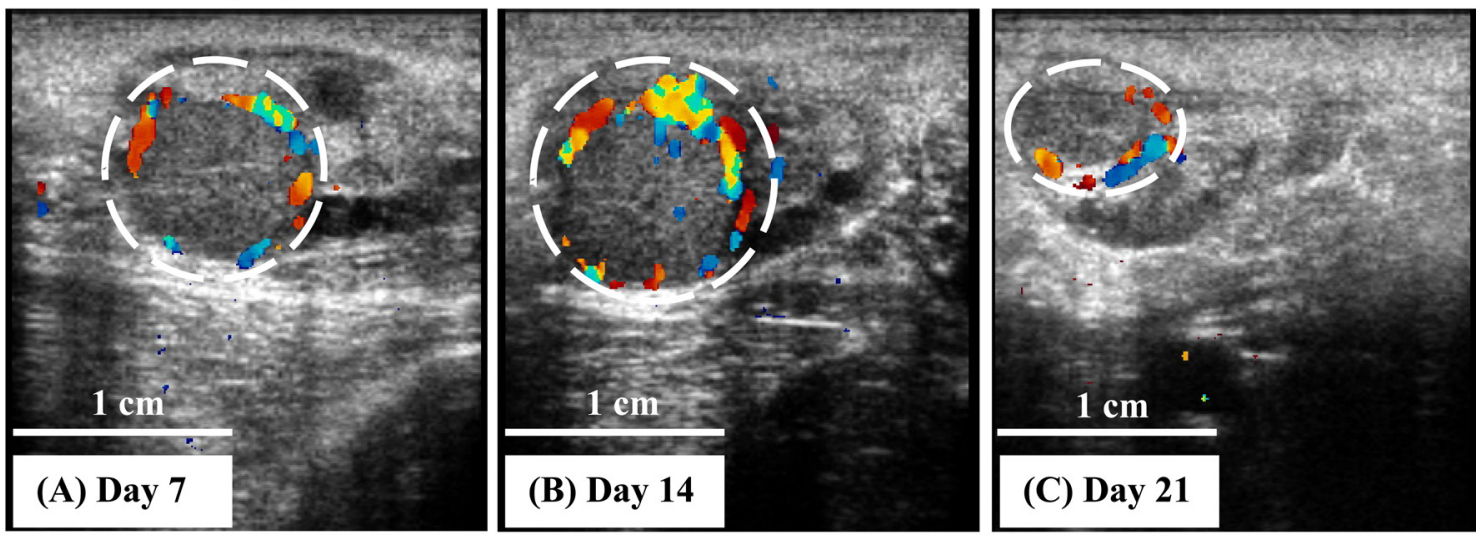

\section{(D - F) Pregnant cows}
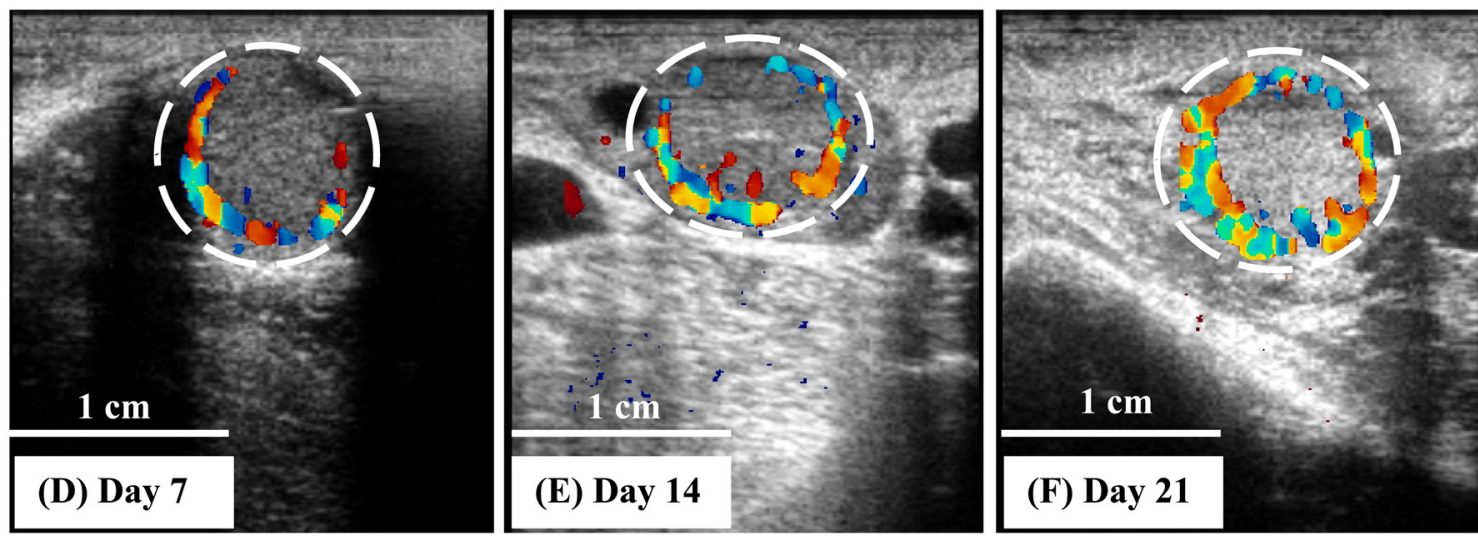

Fig. 4. (A) Representative colour Doppler sonograms of CL and LBF during the first (day 7), (B) second (day 16), and (C) third week (day 21) after AI in non-pregnant Bos indicus dairy cows. (D) Characteristic colour Doppler sonographic images of CL and LBF during the first (day 7) and (E) second week (day 14), which did not regress. (F) The maximum vascularization on third week (day 21) after AI in pregnant Bos indicus dairy cows. The white line circles indicate the region of interest (ROI) used to calculate the cross-sectional area of the CL. Within the ROI, the coloured pixels were quantified using image J software (National Institute of Health, Bethesda, MD, USA) to assess the maximal LBF.

and non-bred dairy cows [24]. The variability in outcomes could be attributed to species differences. This warrants further studies in different species, in order to establish the relationships among LBF, embryo, and $\mathrm{P} 4$ during first three weeks post AI.

The present study indicated that LBF declined dramatically on day 17 after AI in non-pregnant cows. This finding is in accordance with the previous reports where LBF was shown to decrease between days 17 and 21 in non-pregnant crossbred beef cows [23], German Holstein cows [19], Holstein Friesian cows [12], and beef heifers [27]. Previously, it was reported that there is an initial transient increase [17] followed by a decline in LBF within $24 \mathrm{~h}$ due to enhanced secretion of PGF2 $\alpha$ [36], which is an established vasoconstrictor [37]. Moreover, it has been reported that decrease in LBF after luteolysis renders the synthesis of P4 from the luteal cells [19]. Thus, a visual evaluation of LBF in third week represents a quick, reliable, and consistent diagnostic test that would enable the detection of nonpregnant cows [23]. It would be interesting to see if administration of PGF $2 \alpha$ inhibitors enhances the LBF during the third week after
$\mathrm{AI}$ in Bos indicus cows

In the present study, LS showed a significant increase during the first week post AI but remained similar until luteolysis in pregnant and non-pregnant cows. This revealed that CL grows rapidly in pregnant and slowly in non-pregnant cows during the first week post AI. This rapid growth is associated with intensive angiogenesis in early CL due to the abundance of rough endoplasmic reticulum in the cytoplasm of endothelial cells with a loose arrangement in the network of capillaries [38]. Both LBF as well as LS served as an early indicator of CL function compared with $\mathrm{P} 4$, which started to differ only from day 19 post AI between pregnant and non-pregnant cows. This might be because $\mathrm{P} 4$ can only be measured in the peripheral blood and depends not only on the synthesis of P4 from CL, but also on the metabolism in the liver [39].

The present study validated the highly correlated inter-relationships among LS, P4, and LBF during the first three weeks after AI in both pregnant and non-pregnant Bos indicus dairy cows. These observed high correlations are not surprising and were expected, 
as all three parameters are dependent on one structure, i.e., CL. The high association between LBF and P4 in this study, is in close agreement with the earlier results, where correlations were strong between pregnant and non-pregnant Holstein cows [19], dairy heifers [27], and Saanen goats [34]. Traditionally, these variables showed moderate correlation when measured through rectal palpation [40], good correlation when determined via B-mode ultrasonography [41], and very good correlation when measured using CDU [42]. With the advent of CDU, it has now been established that LBF represents an efficient indicator of luteal function. The availability of this information may serve as the basis for the development of disruptive technology in reproduction of dairy cows.

From a practical point of view, early diagnosis of pregnancy is extremely important for proficient reproductive management. The evaluation of LBF on day 17 after AI might be useful for early estrus detection and re-insemination of non-pregnant cows [12]. Previously, it has been reported that LBF on day 21 could be used for resynchronization 9 to 14 days early, compared with the conventional management based on pregnancy diagnosis at days 30 to 35 [13]. In this case, no estrus detection would be required, and AI would occur at the same time as the expected natural return to estrus. Thus, strategies for rapid resynchronization after a diagnosis of non-pregnancy using the LBF on day 17 must be developed and tested on large-scale in dairy herds.

In conclusion, the present study provided new data about the relationships among $\mathrm{LS}, \mathrm{P} 4$, and $\mathrm{LBF}$, and indicated that $\mathrm{LBF}$ is a more sensitive parameter than LS or $\mathrm{P} 4$ to detect the differences in luteal function during the first three weeks after AI between pregnant and non-pregnant Bos indicus dairy cows. Furthermore, this approach could be effectively used to decrease the re-insemination interval, number of open day, and calving interval, for the optimization of reproductive management in dairy cows.

\section{Acknowledgments}

The authors thank Dr Manzoor Ahmad Mangat, Farm Superintendent, Livestock Experimental Station (LES), Jahangirabad, for allowing the use of their cows for this study. The authors are also thankful to Dr Muhammad Shahzad, Scientific Officer, Nuclear Institute for Agriculture and Biology (NIAB) for performing the progesterone assays. This research was supported by a grant from Agricultural Linkages Program (ALP), Pakistan Agricultural Research Council (PARC), Islamabad, Pakistan.

\section{References}

1. Baruselli PS, Reis EL, Marques MO, Nasser LF, Bó GA. The use of hormonal treatments to improve reproductive performance of anestrous beef cattle in tropical climates. Anim Reprod Sci 2004; 82-83: 479-486. [Medline] [CrossRef]

2. Pegorer MF, Vasconcelos JL, Trinca LA, Hansen PJ, Barros CM. Influence of sire and sire breed (Gyr versus Holstein) on establishment of pregnancy and embryonic loss in lactating Holstein cows during summer heat stress. Theriogenology 2007; 67: 692-697. [Medline] [CrossRef]

3. Bennett I, Finch VA, Holmes C. Time spent in shade and its relationship with physiological factors of thermoregulation in three breeds of cattle. Appl Anim Behav Sci 1985; 13: 227-236. [CrossRef]

4. Stagg K, Diskin M, Sreenan J, Roche J. Follicular development in long-term anoestrous suckler beef cows fed two levels of energy postpartum. Anim Reprod Sci 1995; 38: 49-61. [CrossRef]
5. Oltenacu PA, Ferguson JD, Lednor AJ. Economic evaluation of pregnancy diagnosis in dairy cattle: a decision analysis approach. J Dairy Sci 1990; 73: 2826-2831. [Medline] [CrossRef]

6. Stevenson JS, Johnson SK, Medina-Britos MA, Richardson-Adams AM, Lamb GC. Resynchronization of estrus in cattle of unknown pregnancy status using estrogen, progesterone, or both. J Anim Sci 2003; 81: 1681-1692. [Medline] [CrossRef]

7. Pieterse MC, Szenci O, Willemse AH, Bajesy CS, Dieleman SJ, Taverne MA. Early pregnancy diagnosis in cattle by means of linear-array real-time ultrasound scanning of the uterus and a qualitative and quantitative milk progesterone test. Theriogenology 1990; 33: 697-707. [Medline] [CrossRef]

8. Sasser RG, Ruder CA, Ivani KA, Butler JE, Hamilton WC. Detection of pregnancy by radioimmunoassay of a novel pregnancy-specific protein in serum of cows and a profile of serum concentrations during gestation. Biol Reprod 1986; 35: 936-942. [Medline] [CrossRef]

9. Zoli AP, Guilbault LA, Delahaut P, Ortiz WB, Beckers J-F. Radioimmunoassay of a bovine pregnancy-associated glycoprotein in serum: its application for pregnancy diagnosis. Biol Reprod 1992; 46: 83-92. [Medline] [CrossRef]

10. Mialon MM, Renand G, Camous S, Martal J, Ménissier F. Detection of pregnancy by radioimmunoassay of a pregnancy serum protein (PSP60) in cattle. Reprod Nutr Dev 1994; 34: 65-72. [Medline] [CrossRef]

11. Thatcher WW, Bartol FF, Knickerbocker JJ, Curl JS, Wolfenson D, Bazer FW, Roberts RM. Maternal recognition of pregnancy in cattle. J Dairy Sci 1984; 67: 2797-2811. [Medline] [CrossRef]

12. Siqueira LG, Areas VS, Ghetti AM, Fonseca JF, Palhao MP, Fernandes CA, Viana JH. Color Doppler flow imaging for the early detection of nonpregnant cattle at 20 days after timed artificial insemination. $J$ Dairy Sci 2013; 96: 6461-6472. [Medline] [CrossRef]

13. Guimarães CR, Oliveira ME, Rossi JR, Fernandes CA, Viana JH, Palhao MP. Corpus luteum blood flow evaluation on Day 21 to improve the management of embryo recipient herds. Theriogenology 2015; 84: 237-241. [Medline] [CrossRef]

14. Pugliesi G, Miagawa BT, Paiva YN, França MR, Silva LA, Binelli M. Conceptus-induced changes in the gene expression of blood immune cells and the ultrasound-accessed luteal function in beef cattle: how early can we detect pregnancy? Biol Reprod 2014; 91 95. [Medline] [CrossRef]

15. Herzog K, Bollwein $\mathbf{H}$. Application of Doppler ultrasonography in cattle reproduction. Reprod Domest Anim 2007; 42(Suppl 2): 51-58. [Medline] [CrossRef]

16. Acosta TJ, Yoshizawa N, Ohtani M, Miyamoto A. Local changes in blood flow within the early and midcycle corpus luteum after prostaglandin $\mathrm{F}(2 \alpha)$ injection in the cow. Biol Reprod 2002; 66: 651-658. [Medline] [CrossRef]

17. Miyamoto A, Shirasuna K, Wijayagunawardane MP, Watanabe S, Hayashi M, Yamamoto D, Matsui M, Acosta TJ. Blood flow: a key regulatory component of corpus luteum function in the cow. Domest Anim Endocrinol 2005; 29: 329-339. [Medline] [CrossRef]

18. Ginther OJ, Gastal EL, Gastal MO, Utt MD, Beg MA. Luteal blood flow and progesterone production in mares. Anim Reprod Sci 2007; 99: 213-220. [Medline] [CrossRef]

19. Herzog K, Brockhan-Lüdemann M, Kaske M, Beindorff N, Paul V, Niemann H, Bollwein H. Luteal blood flow is a more appropriate indicator for luteal function during the bovine estrous cycle than luteal size. Theriogenology 2010; 73: 691-697. [Medline] [CrossRef]

20. Di Francesco S, Neglia G, Vecchio D, Rossi P, Russo M, Zicarelli L, D'Occhio MJ, Campanile G. Influence of season on corpus luteum structure and function and AI outcome in the Italian Mediterranean buffalo (Bubalus bubalis). Theriogenology 2012; 78: 1839-1845. [Medline] [CrossRef]

21. Figueira LM, Fonseca JF, Arashiro E, Souza-Fabjan J, Ribeiro A, Oba E, Viana J, Brandão FZ. Colour Doppler ultrasonography as a tool to assess luteal function in Santa Inês ewes. Reprod Domest Anim 2015; 50: 643-650. [Medline] [CrossRef]

22. Arashiro EKN, Ungerfeld R, Clariget RP, Pinto PHN, Balaro MFA, Bragança GM, Ribeiro LS, Fonseca JFD, Brandão FZ. Early pregnancy diagnosis in ewes by subjective assessment of luteal vascularisation using colour Doppler ultrasonography. Theriogenology 2018; 106: 247-252. [Medline] [CrossRef]

23. Utt MD, Johnson GL 3rd, Beal WE. The evaluation of corpus luteum blood flow using color-flow Doppler ultrasound for early pregnancy diagnosis in bovine embryo recipients. Theriogenology 2009; 71: 707-715. [Medline] [CrossRef]

24. Herzog K, Voss C, Kastelic JP, Beindorff N, Paul V, Niemann H, Bollwein H. Luteal blood flow increases during the first three weeks of pregnancy in lactating dairy cows. Theriogenology 2011; 75: 549-554. [Medline] [CrossRef]

25. Vecchio D, Neglia G, Gasparrini B, Russo M, Pacelli C, Prandi A, D’Occhio MJ, Campanile G. Corpus luteum development and function and relationship to pregnancy during the breeding season in the Mediterranean buffalo. Theriogenology 2012; 77: 18111815. [Medline] [CrossRef]

26. Šichtař J, Rajmon R, Hošková K, Řehák D, Vostrý L, Härtlová H. The luteal blood flow, area and pixel intensity of corpus luteum, levels of progesterone in pregnant and 
nonpregnant mares in the period of 16 days after ovulation. Czech J Anim Sci 2013; 58: 512-519. [CrossRef]

27. Scully S, Evans AC, Carter F, Duffy P, Lonergan P, Crowe MA. Ultrasound monitoring of blood flow and echotexture of the corpus luteum and uterus during early pregnancy of beef heifers. Theriogenology 2015; 83: 449-458. [Medline] [CrossRef]

28. Varughese EE, Brar PS, Ghuman SS. Vascularization to preovulatory follicle and corpus luteum-a valuable predictor of fertility in dairy cows. Theriogenology 2017; 103: 59-68. [Medline] [CrossRef]

29. Kelley DE, Galvão KN, Mortensen CJ, Risco CA, Ealy AD. Using Doppler ultrasonography on day 34 of pregnancy to predict pregnancy loss in lactating dairy cattle. J Dairy Sci 2017; 100: 3266-3271. [Medline] [CrossRef]

30. Shah S. Animal Husbandry. National Book Foundation Publ. Co. Islamabad 1994.

31. Ferguson JD, Galligan DT, Thomsen N. Principal descriptors of body condition score in Holstein cows. J Dairy Sci 1994; 77: 2695-2703. [Medline] [CrossRef]

32. Kastelic JP, Pierson RA, Ginther OJ. Ultrasonic morphology of corpora lutea and central luteal cavities during the estrous cycle and early pregnancy in heifers. Theriogenology 1990; 34: 487-498. [Medline] [CrossRef]

33. Kanazawa T, Seki M, Ishiyama K, Kubo T, Kaneda Y, Sakaguchi M, Izaike Y, Takahashi T. Pregnancy prediction on the day of embryo transfer (Day 7) and Day 14 by measuring luteal blood flow in dairy cows. Theriogenology 2016; 86: 1436-1444. [Medline] [CrossRef]

34. Balaro MFA, Santos AS, Moura LFGM, Fonseca JF, Brandão FZ. Luteal dynamic and functionality assessment in dairy goats by luteal blood flow, luteal biometry, and hormonal assay. Theriogenology 2017; 95: 118-126. [Medline] [CrossRef]

35. Pinaffi FLV, Araujo ER, Silva LA, Ginther OJ. Color-Doppler signals of blood flow in the corpus luteum and vascular perfusion index for ovarian and uterine arteries during expansion of the allantochorion in Bos taurus heifers. Theriogenology 2017; 102: 35-43. [Medline] [CrossRef]

36. Niswender GD, Reimers TJ, Diekman MA, Nett TM. Blood flow: a mediator of ovarian function. Biol Reprod 1976; 14: 64-81. [Medline] [CrossRef]

37. Azmi TI, O'Shea JD, Lee CS, Rodgers RJ. Effects of a synthetic prostaglandin analogue, cloprostenol, on the corpus luteum of the guinea pig. Prostaglandins 1982; 24: 519-526. [Medline] [CrossRef]

38. Jiang Y-F, Hsu M-C, Cheng C-H, Tsui K-H, Chiu C-H. Ultrastructural changes of goat corpus luteum during the estrous cycle. Anim Reprod Sci 2016; 170: 38-50. [Medline] [CrossRef]

39. Butler WR. Energy balance relationships with follicular development, ovulation and fertility in postpartum dairy cows. Livest Prod Sci 2003; 83: 211-218. [CrossRef]

40. Boyd H, Munro CD. Progesterone assays and rectal palpation in pre-service management of a dairy herd. Vet Rec 1979; 104: 341-343. [Medline] [CrossRef]

41. Kastelic J, Bergfelt D, Ginther O. Relationship between ultrasonic assessment of the corpus luteum and plasma progesterone concentration in heifers. Theriogenology 1990; 33: 1269-1278. [CrossRef]

42. Bollwein H, Heppelmann M, Lüttgenau J. Ultrasonographic doppler use for female reproduction management. Vet Clin North Am Food Anim Pract 2016; 32: 149-164. [Medline] [CrossRef] 